\title{
The global financial crisis: Realities and implications for the Nigerian capital market
}

\author{
${ }^{1}$ Ujunwa Augustine, ${ }^{2}$ Salami Otaru Pius and ${ }^{3}$ Umar, Halidu Ahmed \\ ${ }^{1}$ Department of Banking and Finance, University of Nigeria, \\ Enugu Campus, Enugu State, Nigeria, \\ ${ }^{2}$ Rector, Federal Polytechnic, Nasarawa State, Nigeria, \\ ${ }^{3}$ Department of General Studies, Federal Polytechnic, Nasarawa, Nigeria.
}

\begin{abstract}
This paper examines the impact of the global financial crisis on the Nigerian financial system. The paper documents extensive evidence to show that the immediate past governor of Central Bank of Nigeria was puerile in preventing the global financial crisis from having adverse effect on the Nigerian economy. As a result, the Nigerian capital market was seriously hit by the crisis. The prices of shares in the market nose-dived and investors lost huge sum of money. The crisis also crept into the banking sector as a result of excess exposure to the capital market and oil gas sector. The Central Bank of Nigeria responded simultaneously by injecting $\mathrm{N} 600$ billion into the banking sector. While this effort has been applauded by analysts and justified on the basis of the vital role of banks in economic development. This paper argues that capital market regulators must undertake swift reforms, which will restore public confidence and protect investor. The paper showed that further neglect of the capital market has the implication of stifling the long-term end of the financial system, which will make the financial system atrophied, thus hindering economic growth.
\end{abstract}

Keywords: Global Financial Crisis, Nigerian Capital Market

\section{INTRODUCTION}

The financial crisis ravaging the global economy has generated a very serious concern by all stakeholders. The world has been threatened by several cycles and periods of economic crisis in the past, but the current economic crisis has been described as "a tsunami" (Chossudovsky, 2009). Perhaps, the use of such a strong 'catastrophic' phrase is to properly convey the circumstances and realities of the crisis which is peculiar in terms of its origin, evolution, nature, pace, magnitude, and distressing realities.

There has been a great confusion on the nature of the crisis. According to Sanusi (2009a), "the world economy has been hit by the reperccussion of the financial meltdown that started with the sub-prime mortgage crisis in the United States of America and spread to Europe and other parts of the world". The growing inability to differentiate the current crisis from either an economic problem, a political quandary or an ideological clash even makes the situation more worisome. The pace at which the crisis is affecting economic activity around the world is staggering.
Most OECD countries are are already in recession, and growth in Asia is arguably slowing more rapidly than at any time since 1990 (Summers, 2006).

Predicting and estimating the magnitude of the crisis has shaken the very foundations of international financial markets. The uncontrollable force of globalisation which has torn apart all economic boundaries has not only ravaged all regulatory and protectionist powers of the state, but has actually outspaced and created doubts about the ability of the IMF to contain the crisis (World Bank, 2008). As the world economists independently and jointly reveal their country's survival plans, policies and programmes has shown that the continued reign and existence of capitalist ideology is seriously threatened. Unfortunately, the crisis is further complicated by issues of global concern like climatic change, volatile food and energy prices (Commission for Social Development, 2009).

The current financial and economic crisis has had limited direct impact on African economies largely because of its relatively low financial integration, but 
the crisis has affected the drivers of Africa's recent growth performance. Prior to July, 2008, African economies recorded excellent economic growth performance, despite the 2007 sub-prime mortgage crisis in the United States of America (ADB, 2009). The drivers of the strong economic growth include; macroeconomic reforms; world economic situation that is characterised by high demend for commodities; rising capital inflow; and China's strong economic growth (ADB, 2009). All these factors made analysts believe that the continent is on the verge of breaking away from poverty. However, yesterdays success has eroded with todays realities. The demand for and prices of African commodities are falling largely because of China's slowed growth, capital flight, and promised increased aid has not materialised and might even dissapear depending on how long the crisis lasts (ADB, 2009).

The global financial crisis is already causing a considerable slowdown in most developed countries. The demino effect has led to job losses, speculative burbles in stock markets and commodities markets, reduction in manufacturing as consumption and demand continues to fall. Government around the world are striving earnestly to control the crisis. Market capitalisation is down from its enviable height globally, investment banks are collapsing, rescue packages have been drawn up involving more than twelve trillion US dollars, and interest rates have been cut around the world in what looks like a coordinated response, leading indicators of global economic activities, such as shipping rates, are declining at an alarming rates, while reduction in consumption and demand for manufactured goods have triggered a fall in production and investment in the productive sector (Te Velde, 2008).

Despite the assurance by the Nigerian governmment and the immediate past governor of Central Bank of Nigeria that the global financial crisis will not affect that Nigerian economy, the Nigerian financial system is currently rocked by the financial crisis. Thus, this study is provoked by the fact that when the crisis hit the Nigerian stock market, the Nigerian govvernment did not make any effort to inject liquidity into the market. However, when Nigerian banks were affected due to excess exposure to the capital market and gas oil sector, the government via $\mathrm{CBN}$ was quick to inject six hundred billion naira to enhance bank stability. The CBN has always justified its decision on the important role of bank in economic development, and also to promote banking habit and avoid contagion in the Nigerian banking system. While this line of argument sounds plausible, it seems to suggest that the stock market is a side show, where inefficiencies would merely redistribute wealth between smart investors and noise traders, and would not affect real economic activities. The rest of the paper is divided as follows; Following the introduction is section II which x-rays the impact of the global financial crisis on the Nigerian stock market. Section III reviews how the global financial crisis crept into the banking system and the decision of Central Bank of Nigeria to bailout the affected banks. Section IV looks the implication of bank bailout on strong market development in Nigeria, Section V concludes the paper, while section VI made recommendations on how the looming danger in the financial system can be averted.

Global Financial Crisis and the Nigerian Stock Market: The financial crisis ravaging the global economy is naturally a serious cause for concern to policy makers. Developed economies like USA, Germany, England among other were injecting liquidity into the stock market to safeguard the financial system from crashing. The immediate past governor of Central Bank of Nigeria was busy campaigning that Nigerian investor should not panick, and that the Nigerian financial system is insulated from the global financial crisis. The immediate past governor of Central Bank's position deceived most Nigerian and also afforded foreign investors the opportunity to exit the market at its prime. The immediate past governor of Central Bank of Nigeria also showed little of understanding of the crisis when he argues that "the world economy may not survive the crisis, as it is the beginning of a long period of economic instability that requires policy makers to create an inclusive and responsive global capitalism" (Soludo, 2009). He argued that from the cost of government interventions around the world, other indirect costs of the crisis could run into several trillions of Dollars in income lost, millions of people plunged into poverty for a generation, especially developing countries.

He argues further that "one country could cause a crisis of this magnitude and many countries with sound fundamentals also plunged into a crisis because of the contagous effect, and then the rich ones bail themselves out because they have the resources to do so, while the least developed countries suffer the long-lasting effects of the crisis, is a market-cum system failure of global proportion". In his opinion, the analytical tools for understanding and managing the current system are indequate, and the 
national and global governance infrastructure for resolving or even preventing a resurgence is at best obsolete. This seems to suggest that the then governor of CBN was confuse and do not know what to do to arrest the situation in Nigeria.

This is evident in his statement that "the pace of financial and economic globalalisation appears to have outstripped the pace of the theory and institutions that underlie it. No patchwork will do, a new economic thinking and a new deal by way of fundamental instutional and governance architecture are urgently needed" Thus, he called for a new economic theory that could effectively tackle the crisis. He also criticised the decision of many countries in bailing out the stock markets and banks when he asserts that "one lesson of the current crisis is that policy makers can indeed deepen the crisis by the way they react to it. My hypohesis is that much of the global crisis was aggrevated by the panicky reactions of the policy makers. Politicians, under pressure to be seen to be sensitive to the suffering of masses, sometimes behave like a panicky doctor in an emmergency room who literally decides to administer all the drugs available to a convulsing patient in the hope that, with the cocktail, there is a chance that one of the medicines could get to the ailment"

While the then governor of Central Bank Nigeria was busy canvassing for a new economic model for the global financial crisis, Nigerian investors who were basking on the euphoria that the Nigerian financial system is insulated from the global financial crisis and were caught in the gap. For example, the Nigerian Stock Exchange that witnessed unprecedented growth in total market capitalization and value of share traded for 2004 - early 2008, but is currently experiencing a serious downturn in its activities. According Udeme (2009) the market capitalization of the 303 listed equities., which had opened on January $1^{\text {st }}, 2008$, at N10.18th and later appreciated to N12.395th as at March 2008, suffered its highest fall in the 48-year history of the Nigerian Stock Exchange, depreciating by N3.223tn or 32 per cent to N6.957tn by the year end. Similarly, the NSE All Share Index depreciated by the same margin from $63,016.60$ at which it opened in January, to $31,450.78$ at the last trading day at 2008 (Udeme, 2009).

Although the decline is witnessed in the Nigerian Stock Market, the cause cannot be separated from the global financial crisis. Soludo (2009) again changed his earlier postulation and linked this dwindling fortune of the Nigerian Stock Exchange to global credit crunch. According to him, "the origin of the problem is the credit crunch that started globally". $\mathrm{He}$ posits that the institutional investors were pulling out in order to service their facilities elsewhere and then the stock prices went down. One would have expected that policy makers and the government would prdicted this situation, and take proactive measures to protect investors in the capital market.

On the part of banks in Nigeria, the common argument is that the Nigerian economy draws its strength from the strong internal dynamics rooted in its large population, resilient SMEs, large and vibrant informal sector and the excellent crop of entrepreneurs (Onafowokan, 2009). Also, that Nigerian bank has weak integration into the global financial system, and as such the global financial crisis will not affect Nigerian banks (Onafowokan, 2009). However sound this argument seem, Nigeria banks cannot be insulated from this global financial crisis. Apart from banks various investments in the stock market through their various subsidiaries, some of the banks also have direct exposure to the market: they have given out various margin facilities and loans to the real sector largely backed-up by shares (Oluseyi, 2008). The developed economics have responded to this financial crisis by moving conveniently away from free market fundamentals to a regulated economy regime with the government taking up major stakes in some banks through the injection of funds into these institutions. These cash injections have increased liquidity in the financial system and also shored up economic growth. Despite the assurance from the government that Nigerian financial system is insulated from this global financial crisis, analysts were calling on the government to closely monitor the country's financial system vulnerabilities and be prepared to act promptly (Bayagbon, 2009; Oluseyi, 2008; among others). Priorities may be to inject liquidity into the capital market and banks. However, the government allowed the crisis to degenerate, and only became reactive after millions of Nigerians have lost their investment in the capital market. For instance, the government advised operators in the capital market to reduce their transaction cost, and in adhereing to this call, Securities and Exchange Commission and the Nigerian Stock Exchange decided to cut cost by $50 \%$. This is coming at a time when investors in the cappital market has developed serious apathy for the market. 
Global Financial Crisis and Bank Bailout by Central Bank of Nigeria : Trouble for Nigerian banks, which had seen glorious moments after the 2005 CBN-induced consolidation, started when the global financial crisis crept into the Nigerian capital market (Daily Punch, 2009). With the intention to reap from the market that saw share prices rising astronomically for almost one and half years, most banks neglected the core value of risk management, which is very fundamental to best bank practice and give out loans to corporate bodies and individuals to play in the stock market. Some others also veered into bigger and riskier ventures especially the gas and oil sectors. The carelessness of Nigerian banks in risk management made them vulnerable to the global financial crisis. According to Sanusi (2009b) "the Nigerian banking system appered to have weathered the storm of the global financial crisis due to a number of factors. Among these are the facts that our financial system is not strongly integrated into the international financial system, as well as the relatively simple nature of financial products and strong capitalisation and liquidity of Nigerian Banks. A few Nigerian banks, mainly due to huge concentration of their exposure to certain sectors (capital market and oil and gas being the prodominat ones), but due to general weakness in risk management and corporate governance, have continued to display signs of failure.

According to Sanusi (2009b), a review of the Expanded Discount Window (EDW) revealed that four banks were always using the window and were unable to pay their obligations. Also the fifth has frequently used the window in recent times. Thus an examination of the five banks (Afribank, Finbank, Intercontinental bank, Oceanic bank and Union bank) revealed excessive high level of non performing loans which is attributable to poor corporate governance practice. The total loan portfolio of these banks amounted was N2,801.92 billion, the five banks accounted for a disproportionate component of the total exposure to capital market and oil and gas, that the huge provisioning requirements have led to significant capital impairment, and that the five banks were either the perenial net takers of funds in the inter-bank market or enjoyed support from the the CBN for a very long time, a clear indication of illiquidity (Sanusi, 2009a). The CBN responded to the banking crisis by injecting $\mathrm{N} 400$ billion into the five banks as tier two capital (Sanusi, 2009b).

In furtherance of the CBN,s statutory duty to ensure a sound financial system in the country, the governor of
CBN ordered for the special examination of the remaining banks. After the special examination, four additional banks (Bank PHB, Equitorial Trust Bank, Spring Bank and Wema Bank) were found to be in a grave situation (CBN, 2009). Despite other remedial measures like removing the CEO among others, the CBN also injected a wooping sum of N200 billion into the two banks in form of tier two capital (CBN, 2009).

Ensuring a Sound Banking System: Implication for Stock Market Development in Nigeria: The taxonomy established by Gerschenkron (1962) has led to the distinction of the financial system into bankbased and market-based financial systems, and their relative importance to economic growth, has been the focus of the theoretical debate for over a century (Gerschenkron, 1962; Stiglitz, 1985; Allen and Gale, 1999; Levine, 2002). From empirical literature, attempts are made to examine whether one type of financial system better explains economic growth than another (Arestis and Luintel, 2004). Most empirical findings suggests that both market-based and bank-based financial system promote economic growth (Ujunwa and Salami, 2008).

However, the attitude of regulatory authority in bailing out banks in Nigeria, at the same time allowing investors in the capital market to their fate will promote the banking sector to the detriment of the stock market. This is a dangerous signal to the development of a country's financial system. With the boom in the stock market, so many Nigerians invested their funds in the market, but with the crash in stock market occasioned by the global financial crisis, they lost millions of Naira. Some ran into serious debt, while others committed sucid. If nothing is done to address the continous decline in the prices of shares in Nigeria, Nigerians will loose total confidence in the stock market and may not invest their hard earned fund in the stock market again.

This is another angle to contagion. The implication is that savers deficit will have only one source of funding (Bank). This will also lead to the underdevelopment of the capital market which will make the Nigerian financial system atrophied in nature. The danger with such development is that firms can no longer raise funds from the long-term end of the market. As such, firms in Nigeria will now depend solely on bank funding, which will result in highly levered firms in a volatile economy. This will eventually spell doom for the Nigerian financial system and underpin any meaningful corporate development. 


\section{CONCLUSION}

The global financial crisis has come with its devasting effect on global economies. Government in developed and developing economies are working assudiously to salvage the remains of devasted economies. The decision of the government to bailout the banking sector, while allowing the capital market to gyrate on its own to the detriment of capital market investor might have an adverse effect on the economy. This is more so because savers deficit will be at the mercies of banks. Such development will make the financial system atrophied in nature, encourage banks to misbehave and hurts economic growth in Nigeria on the long-run. The paper recommends that investors in the capital market should also be protected to avoid the underdevelopment of the capital market.

\section{RECOMMENDATIONS}

The capital market is an important component of the financial system because of its peculiar role in the economy. Levine (1991) identified these roles as: raising capital for business, mobilizing savings for investment, facilitating company's growth, redistribution of wealth, promotion of corporate governance, creating investment opportunities for small investors, government capital raising avenue for development projects and barometer of the economy.

As the major source of appropriate long-term funds, the capital market is obviously crucial to any nation's economic development. Specifically, the capital market facilitates economic growth by, among other things, mobilizing savings from numerous economic units such as governments, individuals and institutional investors for users such as governments and the private sector. It also improves the efficiency of capital allocation through a competitive pricing mechanism.

Based on the important role of the capital market, and the staggering negative impact of the global financial crisis on capital market development Nigeria, the government muust restore public confidence in the market and ensure vibrant capital market.

Bank development is very vital in the Nigerian economy. This is more so when one considers the rudimentary stage of the financial system. The Nigerian financial system is cash based, has the inherent capacity to deter effective monetary policy. Thus, the resolve by the current Governor of Central
Bank to improve efficency in the banking system and not allow any bank to fail is a right step in the right direction. This decision is considered very imperative when compared with the contagous effect associated with bank failure.

However, a functional financial system is not made up of banks alone, the capital market is also an important aspect of the financial system. Studies has shown that bank and stock market compliment each other in achieving economic growth. With the global financial crisis, the cpital market and banks were adversely affected. However, the government was swift at proctecting depositor in the banking sector, while allowing investor in the capital market to their fate.

This singular action has the capacity of undermining the development of the stock market. Affected investor will continually shy away from investing in the capital market. This has two implications for the Nigerian economy. Firstly, firms in Nigeria will have only on source of funding (Bank). The implication of this is that the long-term end of the financial system will remain atrophid, and Nigerian firms will be highly levered which translates to higher risk. This will eventually lead to the disappearance of firms.

Secondly, Nigerian economy may suffer from problems associated with bank-based economies. First, in the process of financing firms, banks get access to information that is not availbale to other lenders. Banks can use such inside information to extract rents from firms. More concretely, at the tme of new investments or debt renegotiation, banks can have bargaining power over a firm's expected future profits. Powerful banks can obtain dispropotionately large share of the profits, so that firms will have fewer incentives to undertake high risk and profitable projects.

Second, when banks enter in a debt contract with firms, they have a natural bias towards low risk projects that have a high probability of success. The drawback of this behaviour, however, is that low risk projects are generally low-return investments. Therefore, bank-based financial systems can curtail technological innovation and long-run economic growth. Weinstein and Yafeh (1998) have found evidence in Japan that supports these two points. They show that, while close relationship between banks and firms increase the availability of capital to borrowing firms, they do not necessarily lead to profitabllity or growth. In fact, the cost of capital for firms with close bank ties is higher than that of their 
peers, which suggests that most of the benefits from the these relationships are appropriated by banks. The slow growth rate of bank clients also indicates that banks discourage firms from investing in risky but profitable projects.

Third, powerful banks can collude with managers against outsiders, which in turn impedes competition, corporate controls, the creation of new firms, and thus long-run economic growth. Wenger and Kaserer (1998) provide evidence from Germany where banks misrepresent balance sheet of firms to the public and encourage firm managers to misbehave. Fourth, Allen and Gale (1999) argue that, although intermediaries can be effective at eliminating duplication of information gathering and processing, they can have less success dealing with uncertainty, innovation, and new ideas. For example, the assessment of new technologies is hard either because little information is available about their potential returns because the information itself is difficult to judge without some expertise. The wide range of possibilities and the lack of hard data mean that there is often substantial diversity of opinion. Bank financing requires delegated of the decision regarding the financing of a project to a relatively small number of decision makers. When there is no disagreement, this kind of delegation is very effective and can imply substantial cost savings. A problem, however, exists when diversity of opinion persists.Although mangers do everything they possibly can to choose project they believe are worthwhile (i.e., abstracting from the principal-agent problem), diversity of opinions suggests that some of the providers of fund diagree with those decisions. If the likelihood of disagreement is high enough, investors may have fewer incentives to supply funds.

Consequently, bank-based financial systems imply the underfunding of new technologies. Because market-based systems allow individuals to agree and disagree, and therefore allow coalitions of people with similar views to join together to finance projects, markets are very effective at financing industries that are new, or where relatively no relevant data is created; that is, industires in which little information is available and a diversity of opinion perseveres.

Based on these, this paper recommends that the government should explore ways of restoring confidence in the Nigerian capital market.

First, the government should reinforce adequate regulatory oversight. This can be achieved by significantly enhancing the dual role of effective regulatory oversight and capital market development. This entails tackling weak governance and insufficient capacity as witnessed in the market recently.

Securities laws and rules must be enforced and ensure strict compliance. The Securities and Exchange Commission must strategically place its Compliance Division to ensure that the decisions of its Management on cases of malpractices in the market as well as its administrative directives are complied with. It is generally argued that "In the absence of enforcement and compliance, rules will be broken with impunity and the Commission will be a toothless bulldog which will lead to the erosion of public confidence.

The most effective strategy to efficient capital market is restoring investors' confidence. Public confidence allows activities in the capital market to thrive, since the system will not create room for manipulation. This can be achieved by significantly enhancing the dual role of effective regulatory oversight and capital market development. Oteh (2010) notes that, "these two roles reinforce each other as adequate regulatory oversight fosters a well-functioning capital market".

This entails tackling weak governance and insufficient capacity as witnessed in the market recently. Securities laws and rules must be enforced and ensure strict compliance. The Securities and Exchange Commission must strategically place its Compliance Division to ensure that the decisions of its Management on cases of malpractices in the market as well as its administrative directives are complied with. It is generally argued that "In the absence of enforcement and compliance, rules will be broken with impunity and the Commission will be a toothless bulldog which will lead to the erosion of public confidence".

Second, the most important characteristics of efficient capital market is the flow of information to all market participants. This is a practice where all market participants are equally privilege to information on market condition. This can be achieved through disclosure, transparency and accountability. The absence of effective disclosure, transparency and accountability, undermines the market and creates perverse incentives for those individuals determined to bend the rules (Oteh, 2010). Therefore, the Securities and Exchange Commission must ensure that all public companies disclose meaningful and relevant information to the public. Effective disclosure system thrives with good accounting system. This 
brings to the fore, the importance for the adoption of the International Financial Reporting Standard in Nigeria. The Securities and Exchange Commission can advance this pursuit using the modern information technology innovation to improve disclosure. A very good example is the giant stride by Central Bank of Nigeria, in data intelligence through data capturing machine.

Information symmetry will offer quality and timely information for decision making, which leads to broader investment opportunities for investors. It also restores international confidence as such disclosure requirements conform to international standard, and also help market regulators to detect deviations from the rule.

\section{REFERENCES}

ADB, (2009), "The Impact of the Global Financial and Crisis on Africa", Retrieved on $27^{\text {th }}$ of Octobr 2009 from http://www.themoscowtimes.com/stories/2009/10/10/0 01.html

Allen, F. and Gale, D. (1999), "Diversity of Opinion and Financing of New Technologies", Journal of Financial Intermediation 8: 68-89

Allen, F. and D.Gale (199, Comparing Financial Systems. Cambridge, Mass.: MIT Press.

Arestis, P; Luintel,A.D. and Luintel, K.B. (2004), "Does Financial Structure Matter?"The Levy Economics Institute of Bard College, Annandale-on-Hudson, New York

Bayagbon, M. (2009), Economic Meltdown: IMF Approves Nigeria's Policy, Daily Vanguard of $26^{\text {th }}$ April 5

CBN, (2009), "Press Statement on the Outcome of Special Examination of Fourteen Banks", Retrieved on $27^{\text {th }}$ October, 2009 from http://www.cenbank.org

Chossudovsky, M. (2009), "Global Financial Meltdown: The African Perspective", Retrieved on the $20^{\text {th }}$ of August, 2009 from http://www.global research.ca

Commission for Social Development, (2009), The Current Global Financial Crisis and Their Impact on Social Development, Forty-seventh session, $4^{\text {th }}-13^{\text {th }}$ February

Gerschenkron, A. 1962. Economic Backwardness in Historical Perspective. A Book of Essays. Cambridge, Mass.: Harvard University Press

Levine, R. (1991), "Stock Market, Growth, and Tax Policy", Journal Finance, 46(4): 1445-1465

Levine, R. (2002), "Bank-based or Market-based Financial Systems: Which is Better?"Journal of Financial Intermediation 11 (4): 398-428.
Onafowokan, S. (2009), Nigeria: Global Financial Crisis and Economic Implication, Daily Vanguard of 16 April, 8

Oteh, A. (2010), "A Road Map for Transforming the Nigerian Capital Markets", A Press Briefing at Securities and Exchange Commission Media Centre, Lagos, on the $5^{\text {th }}$ of January.

Oluseyi, B. (2008), "Averting Financial Crisis in Nigeria", Daily Punch of $13^{\text {th }}$ November 6-7

Sanusi, L.S. (2009a), "Developments in the Banking System in Nigeria", An Address Delivered on August $14^{\text {th }}, 2009$.

Sanusi, L.S. (2009b), "An Assessment of Current Development in the Nigerian Economy and the Central Bank of Nigeria (CBN) Policy Action" Retrieved on $27^{\text {th }}$ October, 2009 from http://www.cenbank.org

Soludo, C. (2009), Financial Crisis: Nigeria Must Be Prudent, Daily Punch, $12^{\text {th }}$ of March 4

Stiglitz, J. E. 1985. "Credit Markets and the Control of Capital", Journal of Money, Credit, and Banking 17 (1): 133-152

Summers, L.H. (2006), "Reflection on Global Accounting Imbalances and Emerging Markets Reserves Accumulation"Being Paper Presented at Jha, L.K. Memorial Lecture at Reserve Bank of India on March 24, Retrieved on the $27^{\text {th }}$ of October from http://www.president harvard.edu/speeches/2006/0324_rbi.thtml

Te Velde, D.W. (2008), "The Global Financial Crisis and Developing Countries", InternationalDevelopment Institute Working Paper

Udeme, E. and Onuba, I. (2009), Global Financial Crisis: Keeping the Nigerian Stock Market Viable, Daily Punch of $5^{\text {th }}$ January

Ujunwa, A. and Salami, P.O. (2009), "Does Financial Structure Matter for Economic Growth: Evidence from Nigeria, Duncan Journal (Forth coming)

Weinstein, D.E. and Yafeh, Y. (1998), "On the Costs of a Bank-Centered Financial System:Evidence from the Changing Bank Relations in Japan", Journal of Finance, 53(4), 635-672

Wenger, E. and Kaserer, C. (1998), "The German System of Corporate Governance: A Model Which Should not be Imitated", in S.W. Black and M. Moersch (eds.), Competition and Convergence in Financial Markets: The German and Anglo- American Models, New York: North Holland.

World Bank, (2008), "Global Financial Crisis and Implication for Developing Countries" A Communique Drawn at G-20 Finance Ministers' Meeting at Sao Paulo, Brazil 